\title{
PROMOTER EFFECT OF MICROBES IN SLOPE ECO- ENGINEERING: EFFECTS ON PLANT GROWTH, SOIL QUALITY AND EROSION RATE AT DIFFERENT VEGETATION DENSITIES
}

\author{
NORMANIZA, O. ${ }^{{ }^{*}}-$ AIMEE, H. $^{2}$ - ISMAIL, Y. ${ }^{2}-$ TAN, G. Y. A. ${ }^{1}-$ ROZAINAH, M. Z. ${ }^{1}$ \\ ${ }^{1}$ Institute of Biological Sciences, Faculty of Science, University of Malaya \\ 50603 Kuala Lumpur, Malaysia \\ (phone: +60-3-7967-4185; fax: +60-3-7967-4178) \\ ${ }^{2}$ Department of Geology, Faculty of Science, University of Malaya \\ 50603 Kuala Lumpur, Malaysia \\ (phone: +60-3-7967-7162) \\ *Corresponding author \\ e-mail:normaniza@um.edu.my \\ (Received $1^{\text {st }}$ Jan 2018; accepted $26^{\text {th }}$ Mar 2018)
}

\begin{abstract}
Slope revegetation is claimed to be accelerated with the right choice of plants and effective planting techniques for the root establishment. In addition, microorganisms also promote plant growth via nutrient intensification and soil-root enhancement, hence may alleviate soil surface erosion. Thus, this study is aimed to identify the effects of microbial application on plant growth, soil properties and soil erosion rate at different vegetation densities. Six experimental plots were set up at the Guthrie Corridor Expressway, Selangor, Malaysia, with different amount of microbial application and vegetation density. Dense vegetation cover with microbial application (DM) plot exhibited the highest soil microbes abundance and fungal/bacteria $(\mathrm{F} / \mathrm{B})$ ratio after 24 months of observation. Meanwhile, photosynthetic rate and root length density of Lantana camara in the DM plot revealed the highest rate, followed by Melastoma malabathricum and Bauhinia purpurea. Moreover, the soil of DM plot had also increased in CEC, total N, and respiration rate, reflecting the soil quality. Consequently, erosion rate of DM plot exhibited the $52.6 \%$ of total decrement from the initial experiment. Thus, microbes are proven to be relatively good promoters for the improvement of plant growth performance, the soil quality and alleviate the soil erosion of the slope.
\end{abstract}

Keywords: microbes, vegetation cover, plant growth, soil properties, erosion rate, slope stability

\section{Introduction}

Soil is claimed to be degraded via two domains on slopes; weathering processes and intervention of human activities (Guerra et al., 2017). The torrential rains in tropical regions may elevate the frequency and magnitude of surface erosion processes and subsequently, slope failures (Crozier, 2010). Soil erosion alters the slope environment in various ways, from degrading the soil structure and nutrient content, to contributing to serious landslide tragedies. Although the technical or engineering approaches can be used to provide a significant contribution to mitigate slope instability, replacement of sustainable control of soil erosion such as plant communities is highly desirable. The establishment of vegetative elements has become an alternative approach for slope stabilizing against erosion as well as minimizing the occurrence of landslides (Normaniza and Barakbah, 2011; Liu et al., 2016). Moreover, soil structure itself is not static, but is affected by the activity of plant materials, microbes and plant-microbial interaction (Hawkes et al., 2005). 
The key ecosystem processes of soil habitats are driven by microbial communities, where local assemblages of microorganisms interact with each other and their environment (Konopka, 2009). Generally, similar land-use types usually have similar soil properties and microbial communities (Tian et al., 2017). Hence, we predict that the heterogeneity of cut slope soils may contributes to varying the microbial community and their composition will be highly localized. Soil microorganisms are sensitive to the changes of some environmental factors and play critical part in regulating many ecological processes such as litter decomposition, soil nutrient turnover as well as the plant growth performance (Liu et al., 2010; Wardle et al., 2004). Apart from that, soil microbes have also been reported to have dependency upon soil water availability (Chen et al., 2005; Liu et al., 2009). The soil water availability indirectly influences soil microorganisms via increasing decomposition of litter and soil organic matter (SOM) and subsequently alters the carbon substrates (Risch et al., 2007; Garcia-Pausas et al., 2008). On the other hand, previous studies have found that the bacterial diversity and abundance are influenced by ecological and geological factors such as vegetation type, soil temperature and $\mathrm{pH}$ level that establish the complex interaction among them (Bryant et al., 2008; Young and Crawfor, 2004). Given the revegetation process is an ecologically challenging task of restoring the ecosystem on the "problematic area" (cut slope), together with additional use of commercial biofertilizers, we predict that it will positively affect soil microbial activities and influence on revegetation success as well as the slope stability.

Topography is one of the most important factors controlling revegetation success on slope. Nevertheless, how the vegetation adjusts to terrain effects and the implications of the vegetation-hydrology processes and stability are the most substantial. Vegetation is known to have a major role in slope stability through hydrological and mechanical processes. Mechanical and hydrological processes are strongly interacted to each other and these two processes need to be considered together when assessing the stabilization of slopes by vegetation (Ghestem et al., 2011). Plants establishment on slopes typically intercepts rainfall through dense vegetation cover (Liu et al., 2016; Park and Cameron, 2008), their roots improve the soil structure by modifying aggregate stability (Fattet et al., 2011); and these functions will improve the stability of the slope and enhancing the biodiversity of landscapes (Zou et al., 2012). Additionally, since the topsoil and vegetation were destroyed during the slope cuttings, the slope soil properties are also changed (Chen et al., 2016). Rutigliano et al. (2004) has reported that the vegetation covers significantly affect the soil properties through the input of organic matter to the soil via the carbon and energy supplied from root exudates and plant remains. Whilst other studies have also discovered that as the age of vegetation increased, the soil physical and chemical properties are also enhanced (Zhu et al., 2010; Wang et al., 2015). Therefore, the ability to adapt on the harsh conditions and balance the soil water consumption need to be considered when implementing the vegetation screening for the slope.

From a practical perspective, it is imperative to select the optimal vegetation type that not only effective to control soil erosion, but can also maintain sustainable vegetation restoration (McVicar et al., 2010; Duan et al., 2016). Despite of considering the in situ environmental conditions (e.g. soil and temperature etc.), the easily measurable plant traits with a sound geotechnical basis are also need to be considered (Mickovski et al., 2006). Typically, trees have been used for erosion control, however, they are not recommended for planting on steep slopes because of the risk of uprooting that can cause mass movement (Pawlik, 2013). While the grasses that usually applied 
via hydroseeding are also not guaranteed as the extreme microclimates (e.g. heat stress and shade) can inhibit the establishment of sustainable grass covers and subsequently impair their capabilities for erosion mitigation (Bunnell et al., 2005). In this study, we had chosen shrubs as alternative pioneers that are capable of forming relatively dense evergreen cover on the cut slopes in tropical climate of Malaysia. Lantana camara is a perennial shrub, which is useful in covering the ground with a fine leaf mulch and was found to improve the fertility of soil (Ghisalberti, 2000) as well as exhibited a significantly higher photosynthetic capacity at higher temperatures (Zhang et al., 2014). Whilst Melastoma malabathricum was chosen due to its outstanding capacity to survive in extreme soil conditions and known as an aluminum accumulating plant (Saifuddin et al., 2016; Watanabe et al., 2008). This species exhibited the best physiological performance on slope, which is attributed to high growth rate and the higher planting density contributed in alleviating the erosion rate of slope soils (Aimee and Normaniza, 2015). Another shrub, Bauhinia purpurea was also been selected as it can grow on a dry on hill slopes and has deep root system and high root: shoot ratio, which is suitable for slope stabilization (Orwa et al., 2009). Therefore, these species exhibited the best potential as the slope species. All of the species studied have the root type $\mathrm{M}$ and $\mathrm{VH}$, contributing to surface erosion control and soil reinforcement for slope stabilisation (Saifuddin and Normaniza, 2016)

To date, there is a lack of integral concept related to the interactions between microbes and the soil hydrological properties, soil nutrients content, and plants physiological performance. Thus, this study attempts to relate the microbes (biofertilizer) application on slope towards the growth performance (above-ground and below-ground properties) of the plants chosen and with respect to different plant density. It is anticipated that these findings would enhance the ability of the life growing plant on slopes, modify and improve the soil properties on the slope and reduce soil erosion, resulting in a more stable slope.

\section{Materials and methods}

\section{Study area}

The study area (Fig. 1) is located at the Guthrie Corridor Expressway, Selangor, Malaysia, at the geographical coordinates of $\mathrm{N} 03^{\circ} 13^{\prime} 24.1^{\prime \prime}$ and E $101^{\circ} 30$ '50.2” and annual average precipitation is $2663.34 \mathrm{~mm}$. It has minor rill and minor to moderate gully erosions on the cut slope area with a slope gradient ranging between $26^{\circ}$ to $35^{\circ}$ (temperature $25-32{ }^{\circ} \mathrm{C}$, maximum Photosynthetically Active Radiation (PAR) $2100 \mathrm{mE}$ $\mathrm{m}^{-2} \mathrm{~s}^{-1}$, and relative humidity of $\left.60-75 \%\right)$. Most of the soil texture was dominated by sandy clay loam (moderately to slightly acidic; pH 3.78-5.37). Moreover, this area consisted of Kenny Hill formation, an agglomeration of mixed silts, sands, clays, and even some phyllites which vary from stiff to soft in consistency.

\section{Experimental setup}

In order to avoid the influences of slope aspect, the experimental plots were established on the similar slope properties and aspects (Table 1). Six experimental plots were assigned to three different vegetation coverages; bare (control), less dense (50\% of plant coverage), and dense ( $80 \%$ of plant coverage) with the size of $8 \mathrm{~m} \times 8 \mathrm{~m}$ of each in a complete randomized design (CRD). The buffer zone between the plots was $3 \mathrm{~m}$. 
The second main factor was the bio-fertilizer application with microbe-M and nonmicrobe-NM were applied on each plant coverage; bare (BM and BNM), less dense (LDM and LDNM), and dense (DM and DNM).

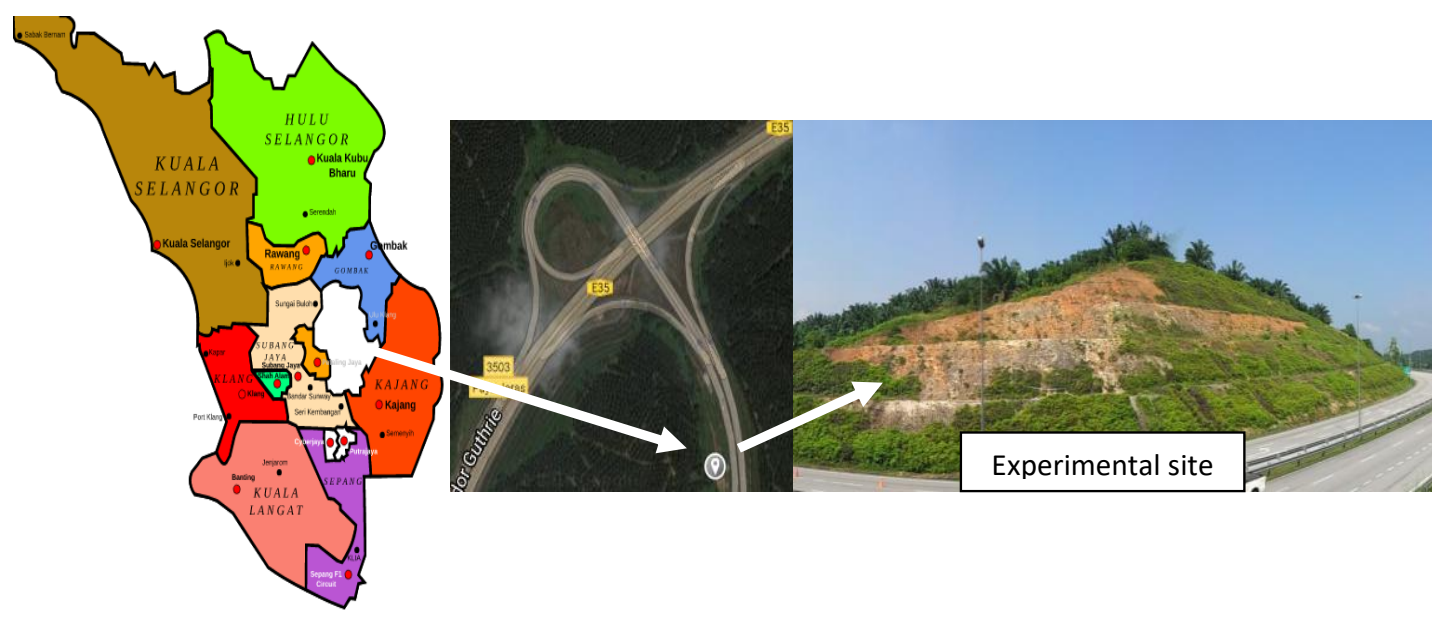

Figure 1. Location of the study area at the Guthrie Corridor Expressway, Selangor, Malaysia

Table 1. Basic information of the selected plots

\begin{tabular}{c|c|c|c|c}
\hline Plot & Slope (\%) & Elevation $(\mathbf{m})$ & Vegetative coverage (\%) & Number of plants \\
\hline Bare & 53 & 63.5 & 0 & 0 \\
Less dense & 55 & 64.1 & 50 & 32 \\
Dense & 57 & 64.5 & 80 & 52 \\
\hline
\end{tabular}

\section{Transplanting technique and microbes (bio-fertilizer) amendment}

Three potential slope plants (as described in the introduction); Lantana camara, Melastoma malabathricum, and Bauhinia purpurea were transplanted onto slopes using a Microclimate Plant Propagation Technique with modified soil depth (Normaniza and Barakbah, 2011). Each seedling was transplanted into holes by using soil coring machine (Eijelkamp Agrisearch Equipment, Model Cobra, The Netherlands) at $0.6 \mathrm{~m}$ of soil depth. Plant supplements: NPK fertilizer, sphagnum moss and rock-phosphate (15 g each/hole) were applied only in the beginning of treatment in order to initiate the establishment of the roots and other physiological processes to take place in a "microenvironment", which could be more conducive for plant establishment and adaptation.

After a week of transplanting, $50 \mathrm{~g}$ bio-fertilizer (containing a consortium of bacteria and fungi) was applied at $10 \mathrm{~cm}$ of soil depth near the transplanted plants, representing the microbe treated plots. Applications were carried out in a single dose and the transplanted plants grew without any management practices.

\section{Measurements}

\section{Isolation and enumeration of soil microbes}

The soil samples $(n=3)$ for each plot were collected four times throughout the twoyear observation. A Soil sample was taken at $10 \mathrm{~cm}$ radius from the stem of the studied plant $(\mathrm{n}=3)$ using sterile spatula and containers. Bacteria and fungi were isolated on 
soil extract agar and potato dextrose agar media, respectively. Soil sample $(1 \mathrm{~g})$ was ten-fold serially diluted with quarter strength Ringer's solution and $100 \mu 1$ of the soil suspension were spread on to agar plates in triplicates. All the agar plates were incubated for 3 to 7 days at $28{ }^{\circ} \mathrm{C}$. Growth of bacteria and fungi were enumerated as colony forming unit per gram of soil (cfu/g).

\section{Plant growth}

Physiological parameters such as photosynthetic rate of the species studied were measured within six months interval and the root length density was measured at the end of the experiment. Photosynthetic rate was measured using a portable photosynthesis system (Li6400XT, LICOR, U.S.A.) in an open system mode, between 1030 and $1230 \mathrm{~h}$ with a Photosynthetically Active Radiation (PAR) ranged between 400 and $2100 \mu \mathrm{E} \mathrm{m}^{-2} \mathrm{~s}^{-1}$.

After twenty-four months, the soils were sampled in triplicates at $0.45 \mathrm{~m}$ of soil depth and $0.1 \mathrm{~m}$ from the plant stem using a soil coring machine (Eijelkamp Agrisearch Equipment, Model Cobra, The Netherlands) to determine the root length density.

\section{Soil physico-chemical properties, respiration rate and erosion rate}

The soil samples of each plot were taken at every six months interval. The samples were air-dried and milled to pass through a $2 \mathrm{~mm}$ sieve and stored in plastic bags prior to laboratory analysis.

Cation Exchange Capacity (CEC) was measured by summing the calcium, magnesium and potassium measured in the soil testing procedure with an estimate of exchangeable hydrogen obtained from the buffer pH (Warncke et al., 1980; Raman and Sathiyanarayanan, 2009). Furthermore, nitrogen content in soil was quantified as the important soil nutrients that affects the plant growth (Sardans et al., 2008) and the microbes are the one that providing a basic mechanism for producing plant-available $\mathrm{N}$ (Huang et al., 2015). Total $\mathrm{N}$ was determined using the modified Kjeldahl method (Bremner and Mulvaney, 1982). Soil respiration was measured at the study site between 1030 and $1230 \mathrm{~h}$ using the closed respiration chamber system $\left(\mathrm{EGM}-4 \mathrm{CO}_{2}, \mathrm{PP}\right.$ Systems, U.S.A.). Each plot was enclosed with $25 \mathrm{~cm}$ height of wooden wall and the eroded soils was channelled to the sediment tank. The eroded soil deposited at the bottom of the tank was calculated in $\mathrm{g} / \mathrm{m}^{3}$.

\section{Statistical analysis}

All the data obtained were analysed by a two-way analysis of variance (ANOVA) test $(\mathrm{P}<0.05)$ using SPSS 20.0 software. Where significant, the first post hoc, least significant difference (LSD) test was calculated to compare the mean values. All results presented in the text are expressed as mean values $(n=3)$. Meanwhile the relationships between variables were determined by using regression analyses.

\section{Results}

\section{Microbial abundance in soil}

The fungal and bacterial abundances were ranged from $4.3 \times 10^{2}$ to $1.8 \times 10^{4}$ and 3.3 $\times 10^{2}$ to $3.7 \times 10^{6} \mathrm{cfu} / \mathrm{g}$, respectively. The F/B ratio varied between 0.02 and 1.52 , being 


$$
-2224 \text { - }
$$

the highest in DM at the end of the experiment (Fig. 2). Fungal and bacterial abundances and the F/B ratio were shown to be affected by microbial application and vegetation density. The $\mathrm{F} / \mathrm{B}$ ratio decreased in all treatments after two years of experiment except for DM and BM treatments.
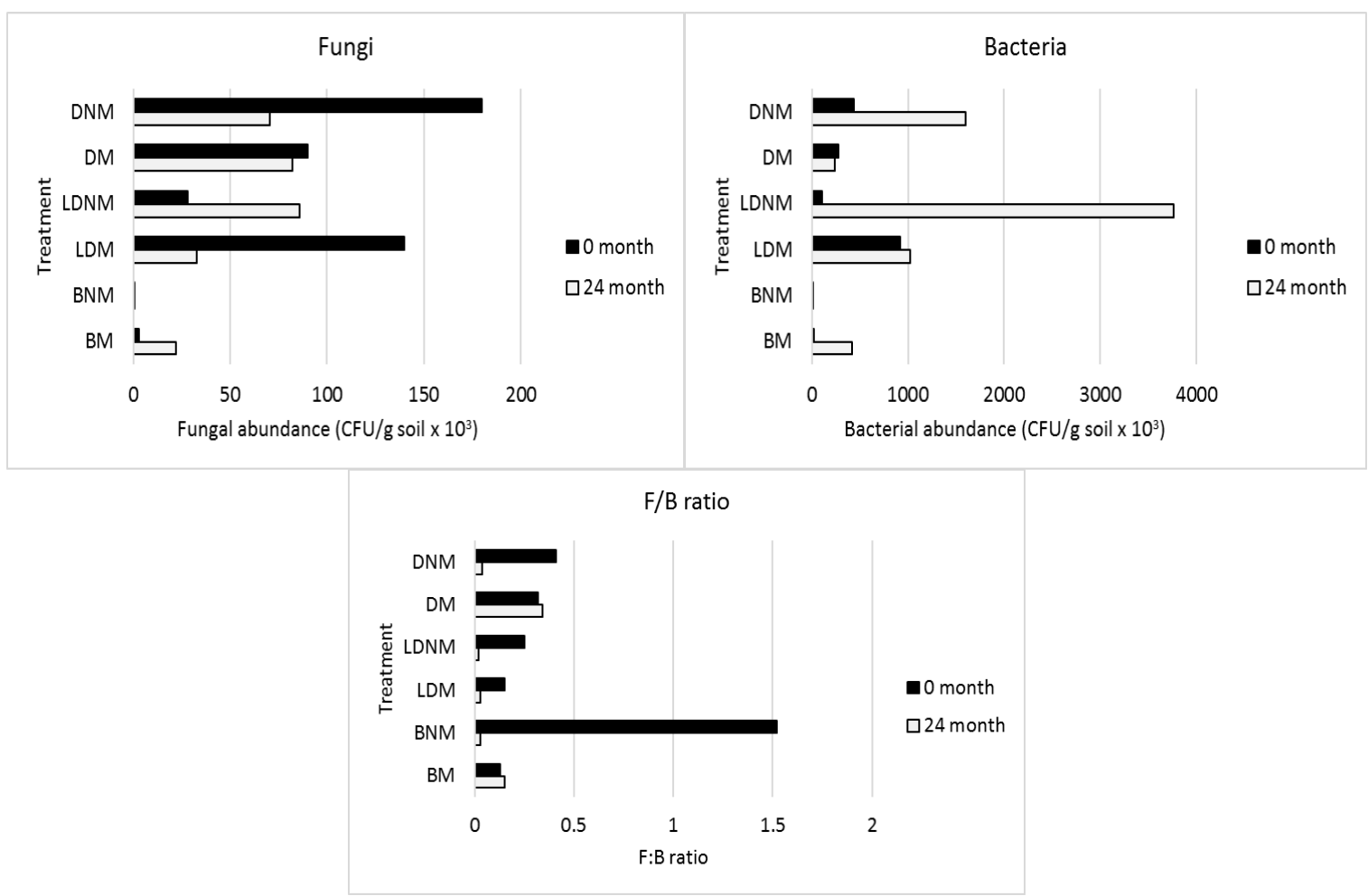

Figure 2. Fungal and bacterial abundances and $F / B$ ratio for microbes and vegetation density treatments on slope

\section{Plant growth performance}

Figure 3 shows the photosynthetic rate and root length density performances of the species studied after a two-year bio-fertilizer application on the vegetation density treatment plots. L. camara in DM plot exhibited the highest photosynthetic rate followed by $M$. malabathricum and $B$. purpurea. In comparison between plots, photosynthetic rate of L. camara in DM plot was higher by $22 \%, 26 \%$ and $29 \%$ than that of in LDM, DNM and LDNM plots, respectively. Similarly, roots of L. camara grew rapidly in DM plot, attaining root length density of $284 \mathrm{~cm} \mathrm{~m}^{-3}$, in which $66 \%$ of a total increment from the early of experiment. Moreover, all the species studied showed the higher total values of root length density in DM plot, followed by the plants in DNM, LDM, and LDNM plots.

\section{Soil properties}

Table 2 shows soil physico-chemical properties and respiration rate at the planting site after 24 months of bio-fertilizer application, grown with dense and less dense of vegetation densities. The microbial application had shown the prominent effects in reducing the porosity especially in the plots with vegetation density treatments (DM and LDM plots). Furthermore, vegetation coverage treatment with the bio-fertilizer 
amendment positively influenced the cation exchange capacity, indicating a greater capacity to hold cations. Whilst the soil $\mathrm{N}$ contents exhibited slightly increment at the end of the experiment except for control plot (BNM). A further analysis of soil performance in comparing between the initial and a 2-year treatment data had gave a better perspective on the changes in respiration rate. A significantly higher respiration rate was observed in microbe-treated soil, with dense plants density (DM plot).
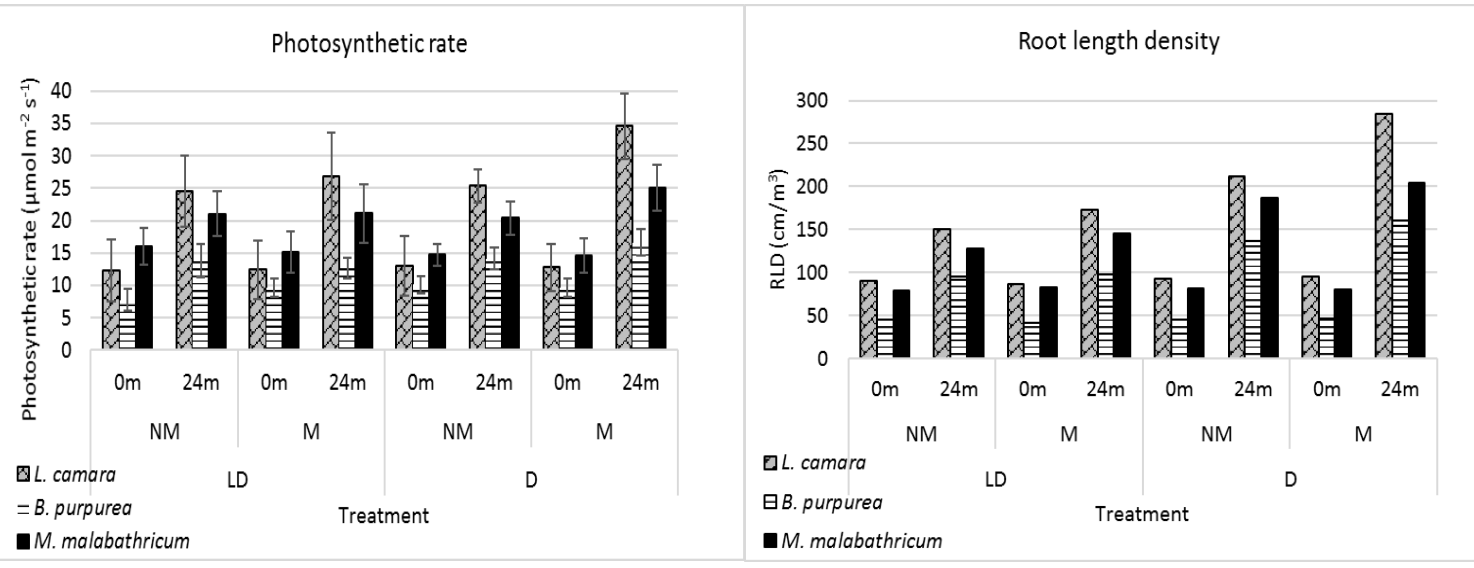

Figure 3. Photosynthetic rate (left) and root length density (right)of the species studied at 0 and 24 month

Table 2. Descriptive data (mean \pm standard deviation) for soil water content, physicochemical properties and respiration rate of the experimental plots

\begin{tabular}{|c|c|c|c|c|c|c|}
\hline & \multicolumn{2}{|c|}{$\underset{\left(\mathrm{cmol}^{(+)} / \mathbf{k g}\right)}{\mathrm{CEC}}$} & \multicolumn{2}{|c|}{$\begin{array}{c}\text { Total N } \\
(\%)\end{array}$} & \multicolumn{2}{|c|}{$\begin{array}{l}\text { Respiration rate } \\
\left(\mathbf{m g ~ C O} \mathbf{C O}_{2} \mathbf{m}^{\mathbf{2}} \mathbf{h}^{1}\right)\end{array}$} \\
\hline & $\mathbf{0 ~ m}$ & $24 \mathrm{~m}$ & $\mathbf{0 ~ m}$ & $24 \mathrm{~m}$ & $\mathbf{0 ~ m}$ & $24 \mathrm{~m}$ \\
\hline DNM & $7.68 \pm 0.3$ & $10.61 \pm 0.4$ & $0.11 \pm 0.03$ & $0.15 \pm 0.04$ & $421.5 \pm 198.6$ & $837.8 \pm 480.3$ \\
\hline $\mathrm{DM}$ & $8.81 \pm 0.4$ & $15.83 \pm 0.6$ & $0.1 \pm 0.01$ & $0.19 \pm 0.03$ & $418.3 \pm 201.1$ & $1103.5 \pm 577.3$ \\
\hline LDNM & $7.13 \pm 0.4$ & $9.55 \pm 0.5$ & $0.09 \pm 0.03$ & $0.11 \pm 0.05$ & $367.8 \pm 115.6$ & $577.7 \pm 268.3$ \\
\hline LDM & $7.58 \pm 0.2$ & $10.33 \pm 0.4$ & $0.14 \pm 0.02$ & $0.17 \pm 0.02$ & $401.2 \pm 187.6$ & $595.6 \pm 331.1$ \\
\hline BNM & $8.16 \pm 0.6$ & $8.04 \pm 0.5$ & $0.12 \pm 0.09$ & $0.11 \pm 0.03$ & $368.9 \pm 200.5$ & $377.4 \pm 189.6$ \\
\hline $\mathrm{BM}$ & $6.97 \pm 0.4$ & $7.52 \pm 0.4$ & $0.09 \pm 0.02$ & $0.11 \pm 0.04$ & $388.1 \pm 211.7$ & $402.5 \pm 225.7$ \\
\hline
\end{tabular}

\section{Erosion rate}

In general, the erosion rates were reduced through time in all treatments except for fluctuated trend observed in bare plot (Fig. 4). It was clear that erosion rate was strongly affected by vegetation type and total plant coverage. DM plot showed the lowest erosion rate, exhibiting the $52.6 \%$ of a total decrement from the initial experiment. Meanwhile, BM and BNM plots were presented inconsistent in erosion rate as no vegetation in these plots, hence, expose to the direct impact of rainfall to the soil surface. 


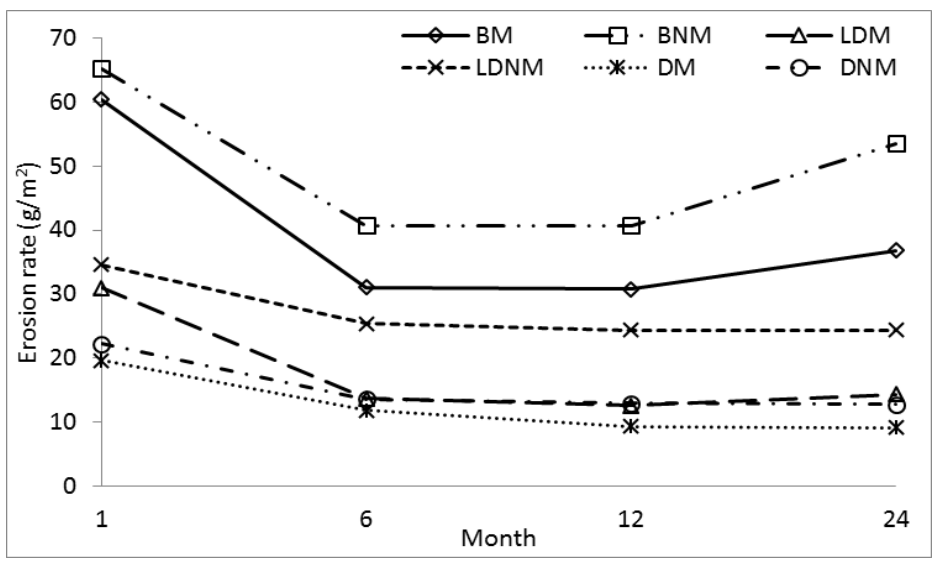

Figure 4. The erosion rates of the experimental plots

\section{Relationship analysis}

Some correlations were also observed in this study. The results showed that there is a relationship between microbes abundance and erosion rate $(\mathrm{R}=0.7$; Fig. 5). Likewise, microbes abundance seemed to have a weak correlation with plant physiology (photosynthetic rate) $(\mathrm{R}=0.3 ;$ Fig. 5).

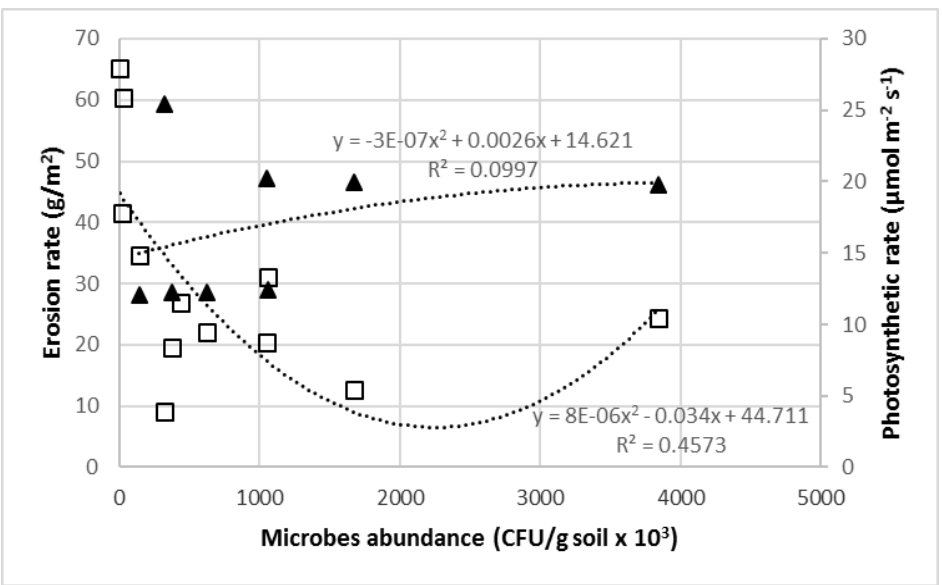

Figure 5. Relationship between microbes, erosion rate and photosynthetic rate of the experimental plots

\section{Discussion}

Our study showed an application of bio-fertilizer (microbes) in higher vegetation density on the slope with the species chosen as the pioneers, marked a positive response in microbe abundance after 24 months of observation (Fig. 2). Generally, in most cases, bacteria dominate under conventional tillage due to a direct contact between bacteria and substrate hence, encouraging the bacterial growth, whereas the fungi dominate under no tillage (Beare et al., 1997). In contrast, based on the abundance of the microbes observed throughout the experiment (Fig. 2), the bacterial abundance that we found were somewhat far higher than the fungal abundance since our study area is considered under no tillage. Finding by Malik et al. (2016) revealed that a lower fungal 
biomass has been linked to lower capacity of such soils to sequester $\mathrm{C}$, material basis of soil fertility. Thus, our finding suggested that the vegetated-plot and the microbe amendment would establish a good condition for plant growth, which resulted in a good plant-soil interaction. Furthermore, a higher vegetation density contributed to the increase of decomposition processes in litter, in which the main decomposition pathways in soil are either bacterial-based or fungal-based (de Vries et al., 2006). Therefore, the biomass of fungi compared to bacteria can be considered as an indicator for the activity of two pathways of the soil food web, represented by fungal: bacterial $(\mathrm{F} / \mathrm{B})$ ratio (Malik et al., 2016).

The F/B ratio has been extensively used in soil ecology particularly in the context of land management (Strickland and Rousk, 2010). While it was not entirely clear the cause in the difference of F/B ratio on the studied plots, it appears to be due to subtle differences in the total of aboveground plants coverage. It indicates that microbial application and higher vegetation density in DM enhance the F/B ratio of the microbial community through ecological complementarity effects such as higher supply of resources for microorganisms (Lange et al., 2014). It was also observed that $\mathrm{F} / \mathrm{B}$ ratio was extremely decreased in the control plot (BNM), implying that the bare surface of soil and direct raindrops impact suppressed the microbial community. Hence, we verify that microbial application and dense vegetation density can probably serve a good condition for microbial communities in soil hence, improve the fertility of soil and provide surface erosion protection.

Apart from that, the microbial application and dense vegetation cover had also shown a significant enhancement in photosynthetic rate and the root length density in plants chosen (Fig. 3). We do not anticipate the results as the high vegetation densities were expected to thrive in the highly competitive plant community. However, our finding verifies the prominent contribution of the species chosen as the outstanding pioneers on the slopes. On the other hand, microbial communities influence the plants by modifying soil structure (e.g. aggregate stability) via litterfall supply (Wallenstein et al., 2007), and by releasing photosynthetic products into the soil, which feeds heterotrophic soil microorganisms (Staddon et al., 2003). In return, soil microbial communities help in obtaining the nutrients for the plant use (Dobermann and Fairhust, 2000) as well as enhancing the soil fertility on slope.

Meanwhile, root reinforcement has been considered as the main mechanical contribution of vegetation to the stability (Yildiz et al., 2015). Throughout the 24 months of experiment, the total root length density (RLD) of DM plot was higher compared to the root densities in other plots (Fig. 3). The results were mainly attributed to high in microbial community and dense vegetation cover, which most likely resulted in increased of water absorption by root and soil water loss through transpiration. Consequently, these plant growth patterns; photosynthetic rate and root length density, had positive effects indirectly and directly, respectively, in increasing the safety aspect of the slope and enhancing the soil stability of the slope.

Based on the two-year observation of physiological performances of the species chosen, L. camara has shown the greater plant growth performance as compared to other species (Fig. 3). This finding was in line with Sharma et al. (2005), in which has described that this invasive species showed an outstanding performance in growth rate on the harsh environment. Thus, this result implies that the sun tolerant feature of $L$. camara as well as having higher number of branching and leaves, resulting in the increased of stomata and subsequently lead to the significant light utilization efficiency 
of the plants in photosynthesis. The second prominent species in this study was shown by M. malabathricum. Study by Aimee and Normaniza (2015) revealed that this species plays an important role as erosion control plant especially on highly eroded areas where it is low in nutrients content. This species also has dense root system that implies the ability of the species to absorb water from the soil. In addition, as the current global warming trend has remarkable changes in temperature and precipitation as well as rising the concentrations of $\mathrm{CO}_{2}$ that may inhibit the plant growth (Parmesan, 2006), thus, we suggest that these two species can serve as good pioneers at the initial phase of succession on the slope.

The microbial application and vegetation density treatments were relatively effective in enhancing soil properties in the studied slope (Table 2). Cation exchange capacity (CEC) is an important measure of the soil's ability to retain and to supply nutrients (Raman and Sathiyanarayanan, 2009). The CEC values of the soils in the study area were affected by microbial amended and vegetation density. Adding microbes to the soil with dense vegetation cover caused a significant increase in the CEC of the soil, suggesting an improvement in soil fertility and nutrient retention (Jien and Wang, 2013). Additionally, further analysis of soil nutrient level comparing the initial and the final properties would give a better perspective on changes in fertility level. Soil with microbial amended and dense vegetation cover showed important improvement in total $\mathrm{N}$, indicating that the presence of heavy litter and humus contents in the surface layers of the studied plot. Hence, the high amount of organic matter may also enhance the richness of $\mathrm{N}$ in the vegetated area as compared to bare surface.

Soil respiration from the soil surface is one of the most important components of the $\mathrm{C}$ cycle in terrestrial ecosystems (Adachi et al., 2006). Soil respiration rates observed in 24-months were greater than those observed at the initial study. Several studies had found that the soil respiration is composed of respiration from both roots and microbes, and there was a relationship between soil respiration and the underground environment (e.g. root and soil microbial biomass) (Søe and Buchmann, 2005; Neergaard et al., 2002). Thus, the high soil respiration rate observed in the microbes applied and dense vegetation cover treatment plots may have been due to high microbial activities.

Concomitant to the positive microbial-vegetation density feedback, soil erosion rates were steadily decreased in all treatments except in the bare plots (Fig. 4). The soil erosion rate decreased significantly in dense vegetation cover, indicating that the microbial incorporation reduced the potential of soil to be eroded. Therefore, based on our results, we deduced that the major reason for reduction of soil loss after the addition of microbes was the extensive integration between microbial community with the plants properties (root system), contributing to the aggregate stability and macroaggregate formation (Cantón et al., 2009), maintaining soil porosity and subsequently decrease the soil erosion.

A strong relationship between microbes abundance and erosion rate $(\mathrm{R}=0.7 ;$ Fig. 5) implies that microbes-plant interaction improve the soil porosity and dense root length density (Fig. 3) could help to reinforce the soil by increasing its shear strength and alleviate the erosion. On the other hand, a weak correlation of microbes abundance with plant physiology (photosynthetic rate) $(\mathrm{R}=0.3$; Fig. 5) indicates that the dense vegetation cover is attributed to the higher in decomposition process, hence, enhance the nutrients available for the plant growth. 


\section{Conclusion}

A two-year observation revealed a positive influence of the microbial application and dense vegetation cover on the slope stability. The performance of the treated plots was accelerated when the promising pioneers, Lantana camara, Melastoma malabathricum, and Bauhinia purpurea were grown together in the plots. In particular, the increased microbes abundance lead to increase in CEC, increase in total $\mathrm{N}$ and respiration rate, indicating the outstanding microbes-plant interaction. The increase of photosynthetic rate and root length density of the species studied was considerably indirect influenced by the microbial activities in soil. In aftermath, positive effect on slope stability was proven in the negative relationship between microbe abundance and erosion rate. It is concluded that microbial amendment in soil with dense vegetation cover could positively influence the plant growth performance and soil quality, which subsequently may alleviate the soil erosion problem of the slope.

Acknowledgements. This work was supported by University of Malaya Research Grant (UMRGRP005A-13SUS, RP005C-13SUS, RP005D-13SUS). The authors are also thankful to the Guthrie Corridor Expressway (GCE) for the use of their slope as experimental site and Myagri Malaysia Sdn. Bhd for the MYCOgold bio-fertilizer supplies throughout this project.

\section{REFERENCES}

[1] Adachi, M., Bekku, Y. S, Rashidah, W, Okuda, T, Koizumi, H. (2006): Differences in soil respiration between different tropical ecosystems. - Applied Soil Ecology 34: 258265.

[2] Aimee, H., Normaniza, O. (2015): The effects of plant density of Melastoma malabathricum on the erosion of slope soil at different slope orientations. - International Journal of Sediment Research 30: 131-141.

[3] Beare, M. H., Hus, S., Coleman, D. C., Hendrix, P. F. (1997): Influences of mycelial fungi on soil aggregation and organic matter storage in conventional and no-tillage soils. - Applied Soil Ecology 5: 211-219.

[4] Bremner, J. M., Mulvaney, C. S. (1982): Nitrogen Total. - In: Page, A. L., Miller, R. H., Keeney, D. R. (eds.) Methods of Soil Analysis. Part 2. Chemical and Microbiological Properties, pp. 595-622. American Society of Agronomy, Madison.

[5] Bryant, J. A., Lamanna, C., Morlon, H., Kerkhoff, A. J., Enquist, B. J., Green, J. L. (2008): Colloquium paper: microbes on mountainsides: contrasting elevational patterns of bacterial and plant diversity. - Proceeding of National Academy of Sciences USA 105(Supplement 1): 11505-11.

[6] Bunnell, B. T., McCarty, L. B., Bridges Jr., W. C. (2005): Evaluation of three Bermuda grass cultivars and Meyer Japanese Zoysiagrass grown in shade. - International Turfgrass Society Research Journal 10: 826-833.

[7] Cantón, Y., Sole-Benet, A., Asensio, C., Chamizo, S., Puigdefabregas, J. (2009): Aggregate stability in range sandy loam soils relationships with runoff and erosion. Catena 77: 192-199.

[8] Chen, S., Ai, X., Dong, T., Li, B., Luo, R., Ai, Y., Chen, Z., Li, C. (2016): The physicochemical properties and structural characteristics of artificial soil for cut slope restoration in Southwestern China. - Scientific Reports 6: 20565.

[9] Chen, T. H., Chiu, C. Y., Tian, G. L. (2005): Seasonal dynamics of soil microbial biomass in coastal sand dune forest. - Pedobiologia 49: 645-653.

[10] Crozier, M. J. (2010): Deciphering the effect of climate change on landslide activity: A review. - Geomorphology 124(3-4): 260-267. 
[11] Dobermann, A, Fairhurst, T. (2000): Rice: Nutrient Disorders and Nutrient Management. - Potash \& Phosphate Institute (PPI), Potash \& Phosphate Institute of Canada (PPIC), and International Rice Research Institute (IRRI), Singapore and Los Baños.

[12] Duan, L., Huang, M., Zhang, L. (2016): Differences in hydrological responses for different vegetation types on a steep slope on the Loess Plateau, China. - Journal of Hydrology 537: 356-366.

[13] Fattet, M., Fu, Y., Ghestem, M., Ma, W., Foulonneau, M., Nespoulous, J., Le Bissonnais, Y., Stokes, A. (2011): Effects of vegetation type on soil resistance to erosion: relationship between aggregate stability and shear strength. - Catena 87: 60-69.

[14] Garcia-Pausas, J., Casals, P., Camarero, L., Huguet, C., Thompson, R., Sebastià, M. T., Romanyà, J. (2008): Factors regulating carbon mineralization in the surface and subsurface soils of Pyrenean mountain grasslands. - Soil Biology and Biochemistry 40: 2803-2810.

[15] Ghestem, M., Sidle, R. C., Stokes, A. (2011): The influence of plant root systems on subsurface flow: implications for slope stability. - BioScience 61: 869-879.

[16] Ghisalberti, E. L. (2000): Lantana camara L. (Verbenaceae). - Fitoterapia 71: 467-486.

[17] Guerra, A. J. T., Fullen, M. A., Jorge, M. C. O., Bezerra, J. F. R., Shokr, M. S. (2017): Slope processes, mass movement and soil erosion: A review. - Pedosphere 27(1): 27-41.

[18] Hawkes, C. V., Wren, I. F., Herman, D. J., Firestone, M. K. (2005): Plant invasion alters nitrogen cycling by modifying the soil nitrifying community. - Ecology Letters 8: 976985.

[19] Huang, Y. M., Liu, D., An, S. S. (2015): Effects of slope aspect on soil nitrogen and microbial properties in the Chinese Loess region. - Catena 125: 135-145.

[20] Jien, S. H., Wang, C. S. (2013): Effects of biochar on soil properties and erosion potential in a highly weathered soil. - Catena 110: 225-233.

[21] Konopka, A. (2009): What is microbial community ecology? - Multidisciplinary Journal of Microbial Ecology 3: 1223-1230.

[22] Lange, M., Habekost, M., Eisenhauer, N., Roscher, C., Bessler, H., Engels, C., et al. (2014): Biotic and abiotic properties mediating plant diversity effects on oil microbial communities in an experimental grassland. - PLoS ONE 9: e96182.

[23] Liu, W., Zhang, Z., Wan, S. (2009): Predominant role of water in regulating soil and microbial respiration and their responses to climate change in a semiarid grassland. Global Change Biology 15: 184-195.

[24] Liu, W., Xu, W., Hong, J., Wan, S. (2010): Interannual variability of soil microbial biomass and respiration in responses to topography, annual burning and $\mathrm{N}$ addition in a semiarid temperate steppe. - Geoderma 158: 259-267.

[25] Liu, Y., Hu, J., Wang, T., Cai, C., Li, Z., Zhang, Y. (2016): Effects of vegetation cover and road concentrated flow on fill slope erosion in rainfall and scouring simulation tests in the Three Gorges Reservoir Area, China. - Catena 136: 108-117.

[26] Malik, A. A., Chowdhury, S., Schlager, V., Oliver, A., Puissant, J., Vazquez, P. G. M., Jehmlich, N., von Bergen, M., Griffiths, R. I., Gleixner, G. (2016): Soil fungal:bacterial ratios are linked to altered carbon cycling. - Frontiers in Microbiology 7: 1247.

[27] McVicar, T. R., Van Niel, T. G., Li, L. T., Wen, Z. M., Yang, Q. K., Li, R., Jiao, F. (2010): Parsimoniously modelling perennial vegetation suitability and identifying priority areas to support China's re-vegetation program in the Loess Plateau: matching model complexity to data availability. - Forest Ecology and Management 259 (7): 1277-1290.

[28] Mickovski, S. B., Bengough, A. G., Bransby, M. F., Davies, M. C. R., Hallett, P. D., Sonnenberg, R. (2006): The effect of roots on soil reinforcement. - Journal of Biomechanics 39: S353.

[29] Neergaard, A., Porter, J. R., Gorissen, A. (2002): Distribution of assimilated carbon in plants and rhizosphere soil of basket willow (Salix viminalis L.). - Plant Soil 245: 307314. 
[30] Normaniza, O., Barakbah, S. S. (2011): The effect of plant succession on slope stability. - Ecological Engineering 37: 139-147.

[31] Orwa, C., Mutua, A., Kindt, R., Jamnadass, R., Simons, A. (2009): Agroforestree Database: A Tree Reference and Selection Guide Version 4.0. - World Agroforestry Centre, Kenya.

[32] Park, A., Cameron, J. L. (2008): The influence of canopy traits on through fall and stemflow in five tropical trees growing in a Panamanian plantation. - Forest Ecology and Management 255: 1915-1925.

[33] Parmesan, C. (2006): Ecological and evolutionary responses to recent climate change. Annual Review of Ecology, Evolution, and Systematics 37: 637-669.

[34] Pawlik, Ł. (2013): The role of trees in the geomorphic system of forested hillslopes - a review. - Earth-Science Reviews 126: 250-265.

[35] Raman, N., Sathiyanarayanan, D. (2009): Physico-chemical characteristics of soil and influence of cation exchange capacity of soil in and around Chennai. - Rasayan Journal of Chemistry 2(4): 875-885.

[36] Risch, A. C., Jurgensen, M. F., Frank, D. A. (2007): Effects of grazing and soil microclimate on decomposition rates in a spatio-temporally heterogeneous grassland. - Plant Soil 298: 191-201.

[37] Rutigliano, F., D'ascoli, R., Virzo De Santo, A. (2004): Soil microbial metabolism and nutrient status in a Mediterranean area as affected by plant cover. - Soil Biology and Biochemistry 36: 1719-1729.

[38] Saifuddin, M., Normaniza, O., Rohailah, M. I., Aimee, H. (2016): The effects of prealuminum treatment on morphology and physiology of potential acidic slope plants. Kuwait Journal of Science 43(2): 139-160.

[39] Saifuddin, M., Normaniza, O., (2016): Rooting characteristics of some tropical plants for slope protection. - Journal of Tropical Forest Science 28(4): 469-478.

[40] Sardans, J., Peñuelas, J., Estiarte, M. (2008): Changes in soil enzymes related to C and N cycle and in soil $\mathrm{C}$ and $\mathrm{N}$ content under prolonged warming and drought in a Mediterranean shrubland. - Applied Soil Ecology 39(3): 223-235.

[41] Sharma, G. P., Raghubanshi, A. S., Singh, J. S. (2005): Lantana invasion: An overview. Weed Biology and Management 5: 157-165.

[42] Søe, A. R. B., Buchmann, N. (2005): Spatial and temporal variations in soil respiration in relation to stand structure and soil parameters in an unmanaged beech forest. - Tree Physiology 25: 1427-1436.

[43] Staddon, P. L., Ramsey, C. B., Ostle, N., Ineson, P., Fitter, A. H. (2003): Rapid turnover of hyphae of mycorrhizal fungi determined by AMS microanalysis of ${ }^{14} \mathrm{C}$. - Science 300 : 1138-1140.

[44] Strickland, M. S., Rousk, J. (2010): Considering fungal:bacterial dominance in soils Methods, controls, and ecosystem implications. - Soil Biology \& Biochemistry 42: 13851395.

[45] Tian, Q., Taniguchi, T., Shi, W. Y., Li, G., Yamanaka, N., Du, S. (2017): Land-use types and soil chemical properties influence soil microbial communities in the semiarid Loess Plateau region in China. - Scientific Reports 7: 45289.

[46] Wallenstein, M. D., McMahon, S., Schimel, J. (2007): Bacterial and fungal community structure in Arctic tundra tussock and shrub soils. - FEMS Microbiology Ecology 59: 428-435.

[47] Wang, J. J., Hu, C. X., Bai, J., Gong, C. M. (2015): Carbon sequestration of mature black locust stands on the Loess Plateau, China. - Plant Soil Environment 61: 116-121.

[48] Wardle, D. A., Bardgett, R. D., Klironomos, J. N., Setälä, H., Putten, W. H., Wall, D. H. (2004): Ecological linkages between aboveground and belowground biota. - Science 304: $1629-1633$. 
[49] Warncke, D. D., Robertson, L. S., Mokma, D. L. (1980): Cation Exchange Capacity Determination for Acid Calcareous Michigan Soils. - In: Agronomy Abstracts. ASA, Madison, WI, 147.

[50] Watanabe, T., Misawa, S., Hiradate, S., Osaki, M. (2008): Root mucilage enhances aluminium accumulation in Melastoma malabathricum, an aluminium accumulator. Journal of Plant Signaling and Behavior 3(8): 603-605.

[51] Yildiz, A., Askarinejad, A., Graf, F. Rickli, C., Springma, S. M. (2015): Effects of roots and mycorrhizal fungi on the stability of slopes. - Proceedings of the XVI ECSMGE Geotechnical Engineering for Infrastructure and Development, pp. 1693-1698.

[52] Young, I. M., Crawford, J. W. (2004): Interactions and self-organization in the soilmicrobe complex. - Science 304(5677): 1634-7.

[53] Zhang, Q., Zhang, Y., Peng, S., Zobel, K. (2014): Climate warming may facilitate invasion of the exotic shrub Lantana camara. - PLoS ONE 9(9): e105500.

[54] Zhu, B., Li, Z., Li, P., Liu, G., Xue, S. (2010): Soil erodibility, microbial biomass, and physical-chemical property changes during long-term natural vegetation restoration: a case study in the Loess Plateau, China. - Ecological Research 25: 531-541.

[55] Zou, M., Zhu, K. H., Yin, J., Gu, B. (2012): Analysis on slope revegetation diversity in different habitats. - Procedia Earth Planetary Science 5: 180-187. 